Abstracta Iranica Abstracta Iranica

Revue bibliographique pour le domaine irano-aryen

Volume 25 | 2004

Comptes rendus des publications de 2002

\title{
La recherche archéologique française au Moyen-Orient 1842-1947. Paris, Éditions Recherche sur les Civilisations, 2002, 630 p.
}

\section{Rémy Boucharlat}

\section{CpenEdition}

1 Journals

\section{Édition électronique}

URL : http://journals.openedition.org/abstractairanica/4050

ISSN : 1961-960X

Éditeur:

CNRS (UMR 7528 Mondes iraniens et indiens), Éditions de l'IFRI

Édition imprimée

Date de publication : 15 mai 2004

ISSN : 0240-8910

\section{Référence électronique}

Rémy Boucharlat, «La recherche archéologique française au Moyen-Orient 1842-1947. Paris, Éditions Recherche sur les Civilisations, 2002, 630 p. », Abstracta Iranica [En ligne], Volume 25 | 2004, document 15, mis en ligne le 15 mars 2006, consulté le 25 septembre 2020. URL : http://

journals.openedition.org/abstractairanica/4050

Ce document a été généré automatiquement le 25 septembre 2020.

Tous droits réservés 


\title{
La recherche archéologique française au Moyen-Orient 1842-1947. Paris, Éditions Recherche sur les Civilisations, 2002, 630 p.
}

\author{
Rémy Boucharlat
}

1 Depuis l'initiative individuelle des consuls français, plus ou moins soutenus par leur ministère de tutelle, des résidents en Mésopotamie, alors dans l'empire ottoman, jusqu'à la création d'une Commission des Fouilles au Ministère des Affaires Étrangères, N.C. donne une véritable histoire de l'archéologie française en Orient. Le contexte de ces recherches est omniprésent, d'abord l'attitude des autorités françaises, faisant de ces pages une véritable histoire des mentalités - avec les divergences entre les savants et les politiques - ensuite de la politique de la France dans cette région. L'un et l'autre illustrent bien la stratégie des gouvernements français qui veulent marquer leur présence plus par les activités culturelles que par la pénétration économique. La Perse de l'époque en est une parfaite illustration : tandis que la Russie et la Grande-Bretagne se partage le pays, le dominant politiquement et économiquement, la France obtient le monopole des fouilles sur tout le territoire. Mais la comparaison menée avec la stratégie menée dans les autres pays de la région est instructive. La première guerre mondiale marque une rupture nette partout, amenant à une redéfinition des objectifs et de la stratégie.

2 La Délégation en Perse est un cas original, une volonté marquée par la nostalgie de l'expédition de Bonaparte en Égypte. En tant que telle elle aura finalement une brève existence (1897-1912), mais les activités de archéologues français resteront importantes (jusqu'à la fin du monopole en 1927) et très visibles dans le paysage. Cette histoire de l'archéologie en Perse occupe $1 / 5$ du livre.

3 Archiviste de formation, N. Chevalier a scruté les documents officiels et en donne de larges extraits sous la forme de précieuses annexes (95p.). Délibérément, seules les archives françaises sont exploitées; à partir de ce travail exemplaire, il reste à 
entreprendre des recherches similaires sur les archives des pays concernés (travaux en cours pour l'Iran).

INDEX

Thèmes : 1.3. Ouvrages généraux, histoire de la discipline

\section{AUTEURS}

\section{RÉMY BOUCHARLAT}

CNRS - Lyon 